\title{
Bromatologic composition of the herbaceous species of the Northeastern Brazil Caatinga ${ }^{1}$
}

\section{Divan Soares da Silva², Maria Verônica Meira de Andrade ${ }^{3}$, Alberício Pereira de Andrade ${ }^{4}$, Maria Socorro de Souza Carneiro ${ }^{5}$, Juliana Silva de Oliveira ${ }^{6}$}

\author{
1 Projeto financiado pelo CNPq. \\ 2 UFPB - Universidade Federal da Paraíba, Pesquisador II CNPq \\ 3 Programa de Doutorado Integrado em Zootecnia PDIZ/UFPB. \\ 4 INSA - Instituto Nacional do Semiárido. Pesquisador II CNPq. \\ 5 UFC - Universidade Federal do Ceará. \\ ${ }^{6}$ UFPB - Universidade Federal da Paraíba.
}

ABSTRACT - The objective of this work was to evaluate the chemical composition of the pool and of four species of caatinga herbaceous vegetation in the rainy and dry seasons. The experiment was conducted in three selected shrub areas at different levels of conservation. Four samples of each species (Arachis pintoi, Boerhavia diffusa, Heliotropium ternatum, Aristida adscensionis) were collected in each area and from a pool of species for determination of bromatologic composition. In the dry season, only the pool of species and the grass Aristida adscensionis were evaluated. There was a significant effect of the studied area on the chemical composition of all analyzed species. The nutrient content found in the dry matter (DM) and the digestibility of the pool of species indicate that caatinga herbs presented improved quality in the rainy season. The qualitative variables of the studied species were most heterogeneous due to the variability found in caatinga. Conservation conditions in caatinga and season of the year influence bromatologic composition of the species Arachis pintoi, Boerhavia diffusa L., Heliotropium ternatum Vahl. Aristida adscensionis L. and of a pool of typical species found in Caatinga.

Key Words: herbs, native species, quality, semiarid

\section{Composição bromatológica de espécies herbáceas da caatinga}

RESUMO - Com o objetivo de avaliar a composição bromatológica do pool e de quatro espécies da vegetação herbácea da caatinga nos períodos chuvoso e seco foi conduzido um experimento em três áreas selecionadas de caatinga, com níveis diferenciados de conservação. Em cada área, foram colhidas quatro amostras de cada espécie (Arachis pintoi, Boerhavia diffusa, Heliotropium ternatum, Aristida adscensionis) e de um pool de espécies, para determinação da composição bromatológica. $\mathrm{Na}$ época seca foram avaliados somente o pool de espécies e a gramínea Aristida adscensionis. Houve efeito significativo da área amostrada na composição bromatológica de todas as espécies analisadas. Os teores de nutrientes na matéria seca (MS) e a digestibilidade do pool das espécies indicam que as ervas da caatinga apresentaram melhor qualidade na época chuvosa. As variáveis qualitativas das espécies analisadas mostraram-se heterogêneas, devido à variabilidade encontrada na caatinga. As condições de conservação da caatinga e o período do ano influenciam a composição bromatológica das espécies Arachis pintoi, Boerhavia diffusa L., Heliotropium ternatum Vahl. e Aristida adscensionis L. e de um pool de espécies típicas da caatinga.

Palavras-chave: ervas, espécies nativas, qualidade, semiárido

\section{Introduction}

The Northeastern region in Brazil is characterized by having two well-defined climatic periods along the year: a wet and a dry season. During the rainy period, the caatinga vegetation re-grows, giving rise to an herbaceous layer, which possesses a large variety of plants, most of them with enormous forage potential. Over $80 \%$ of all herbaceous and woody species in the caatinga are used to feed all domestic ruminants (Lee et al., 1996) and they are very important for soil conservation, water retention in the ecosystem and for the supply of forest products, such as stakes and firewood (Araújo \& Ferraz, 2003).

One striking feature of the semi-arid regions is their high temperatures, which can directly affect the quality of the available forage. High temperatures promote rapid cell wall lignifications, accelerating the cellular metabolic activity, and resulting in decreased pool of metabolites in cellular content. They also promote the rapid conversion of photosynthetic products in the cell wall components (Van Soest, 1965). 
Soil moisture affects forage plants directly. Severe water stress, as it often occurs in the semiarid, promotes growth paralysis and death of aboveground plant. This limits livestock production, both because of low quality and low availability of the forage shortage.

Despite its rich variety of plant species on the herbaceous layer and their important role in the diet of goats and sheep - mainly during the rainy season - little is known about caatinga, where the bromatologic composition of these species is concerned. So, a detailed study of the caatinga may provide some useful information as to what forms of management can be used to improve the use of its varied species.

Santos et al. (2009) evaluated the chemical composition of the diet of sheep grazing on the shrubs during the rainy season (March 2005). They observed that the sheep diet presented the following values: $\mathrm{CP}=14.43 \%$; $\mathrm{NDF}=54.83 \%$; $\mathrm{ADF}=39.98 \%$; $\mathrm{CT}=67.69 \%$ and $\mathrm{CNF}=12.86 \%$. Rapini et al. (2006) stated that, knowing the semiarid biodiversity and its physical-chemical and biological processes which affect its biota constitutes is the first step towards an efficacious use of its resources with sustainability, reducing, therefore, environmental degradation.

Considering the fact that the caatinga vegetation presents a diversity of flora, consisting of herbaceous species, shrubs and trees of several families - mainly formed with plants used as animal food - there comes the need for additional studies to work out a better quality evaluation of these plants in connection with their nutritional value.

Consequently, the objective of this work is to evaluate the chemical composition of the caatinga herbaceous species on three areas at different degrees of conservation, namely the Cariri of Paraiba in rainy and dry years.

\section{Material and Methods}

The present study was conducted at the Estação Experimental at the Universidade Federal da Paraíba, located in the municipality of São João do Cariri on a 320-ha area of gentle, undulating topography whose dominant vegetation consists of the caatinga shrub-trees.

The climate in the region, according to Köppen, is Bshhot semi-arid with summer-autumn rains. According to bioclimatic classification of Gaussen, the climate is hot Subdesert tending towards tropical with a climate characterized by poor and irregular rainfalls (annual and inter-annual). In 2007, the rainfall recorded at the Estação Experimental was $362.6 \mathrm{~mm}$ (Figure 1 ).

The average annual temperature is $26^{\circ} \mathrm{C}$ with a minimal temperature of $18^{\circ} \mathrm{C}$ and a maximal temperature of about $34^{\circ} \mathrm{C}$. The hottest time of the year is from November to January whereas the coldest period is in July. The average air relative humidity is $70 \%$. Data on rainfall, humidity and temperature used in this study were obtained in the year 2007, from the database of a conventional weather station located at the Estação Experimental of São João do Cariri (Figure 2).

Three Caatinga areas were selected in different stages of secondary succession. Area 1 was the least preserved area; Area 2 was of intermediate preservation, and Area 3 was the most preserved, exhibiting the densest vegetation. In these areas, a floristic survey was conducted to identify botanical species. For this purpose it was collected and prepared voucher specimen of plant material, which was taken to the Laboratório de Botânica Jayme Coelho de Morais CCA / UFPB for identification. In all three areas, the caatinga presented sized scrub-trees, with higher proportion of shrubs and higher incidence of Aristida adscensionis L., far more noticeable in areas 1 and 2.

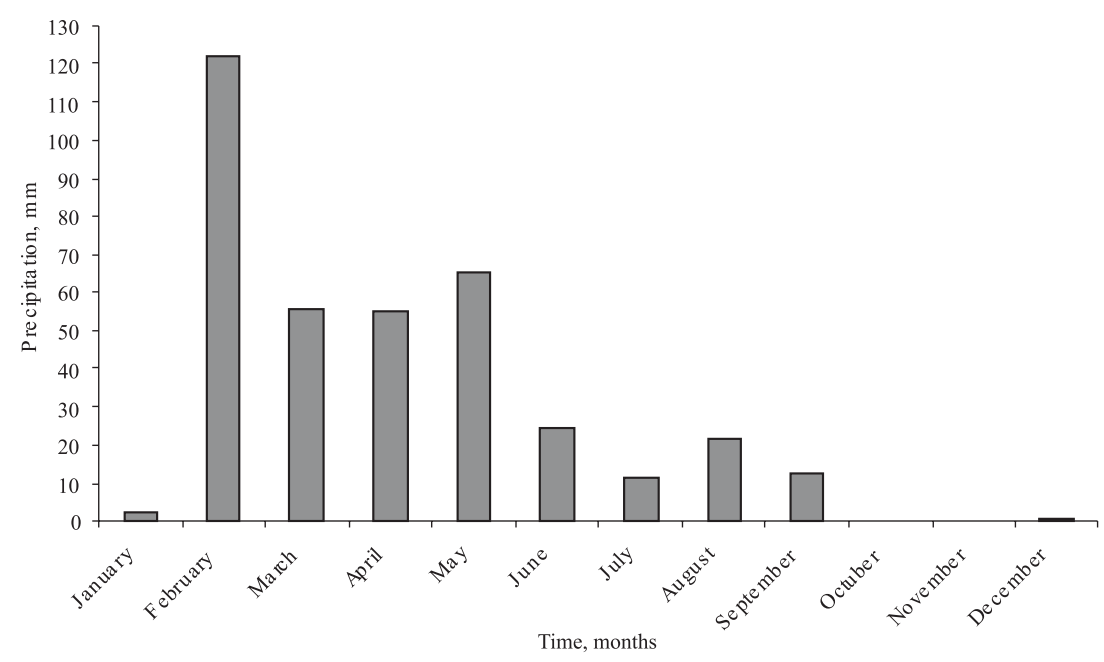

Figure 1 - Monthly rainfall recorded at the Experimental Station in 2007 (annual precipitation = $362.6 \mathrm{~mm}$ ). 
The selected areas were characterized by presenting the species Sida sp. Lippia gracillis Schauer, Croton sonderianus Müll. Arg., Caesalpinia pyramidalis Tul., Jatropha mollissima (Pohl) Baill., Aspidosperma pyrifolium Mart., and some cacti, such as Cereus jamacaru DS., Pilocereus gounellei F. Ritter, besides the herbaceous layer from where the species selected for this study were originated.

For the physicochemical characterization of the three experimental sites, soil samples were collected from an approximately depth of $20 \mathrm{~cm}$. The samples were taken to the Laboratório de Análise de Solos e Água do CCA/UFPB of the CCA/UFPB. Measurements consisted of particle size analysis, clay dispersion and flocculation, soil bulk density and particle, total porosity and water available in soil at 0.01 and $1.5 \mathrm{MPa}$, according to the methodology proposed by Forsythe (1975). The chemical analysis consisted of water $\mathrm{pH}$, phosphorus, potassium, calcium, magnesium, aluminum, sodium and organic matter as ruled by methodologies recommended by EMBRAPA (1997) (Table 1).

Three species of herbaceous dicots (Arachis pintoi, Boerhavia diffusa L. Heliotropium ternatum Vahl.) were identified, and a monocot (Aristida adscensionis L.) and a pool of species were identified for bromotologic analyzes (Table 2). The criterion for the choice of species was based on the natural preference of goats and sheep, according to field observations, coupled with greater amount of biomass presented in these species.

Samples of these plants were collected to determine their bromatologic values in two seasons: rainy season (April) and dry season (August). In the rainy season, four species of herbs and pool were collected, and in dry season, it was only possible to collect the Aristida adscensionis L. and the pool because the other species only come up in these areas in the rainy season.

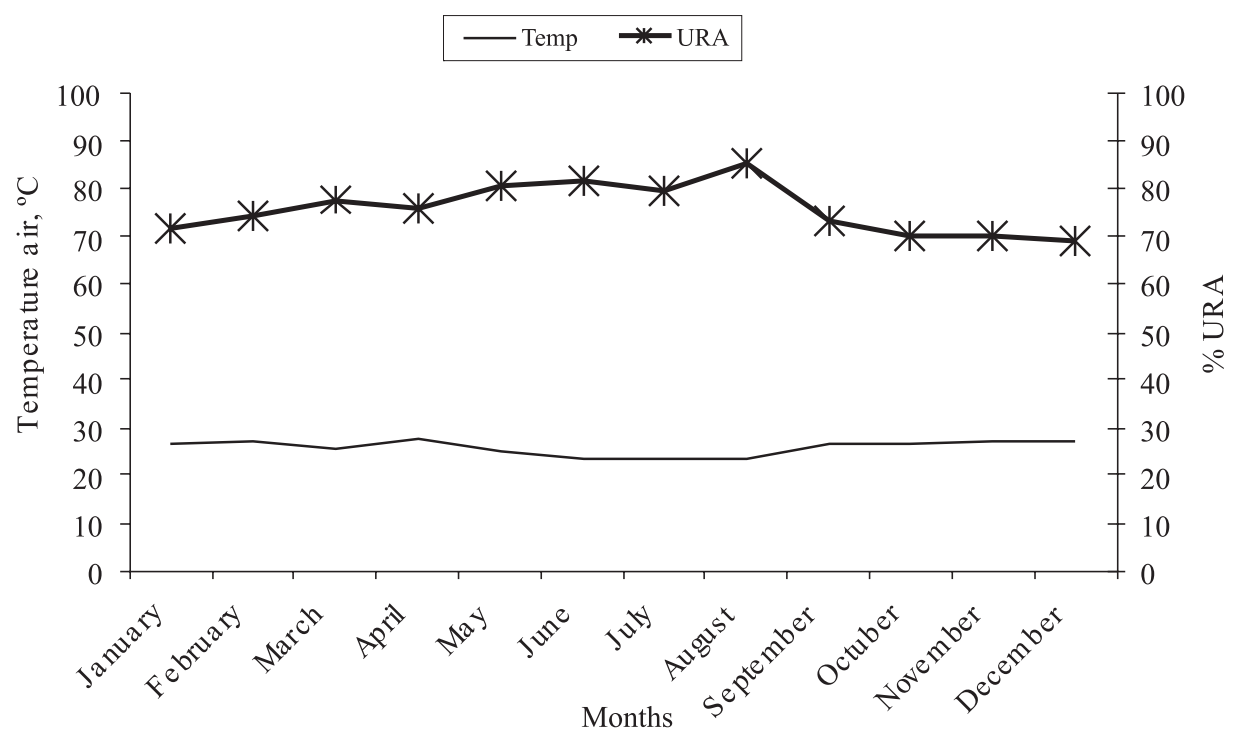

Figure 2 - Average temperature and relative humidity in 2007 at the Experimental Station of São João do Cariri, Paraíba.

Table 1 - Chemical and physical analysis of soil samples from areas located at the experimental station

\begin{tabular}{|c|c|c|c|c|c|c|c|c|c|c|c|}
\hline \multirow[t]{2}{*}{ Area } & \multicolumn{3}{|c|}{ Particle size } & \multirow{2}{*}{$\begin{array}{l}\text { Dispersed } \\
\text { clay }\end{array}$} & \multirow[t]{2}{*}{ Flocculation } & \multicolumn{2}{|c|}{ Density } & \multicolumn{3}{|c|}{ Humidity } & \multirow{2}{*}{$\begin{array}{c}* \text { Texture } \\
\text { class }\end{array}$} \\
\hline & $\begin{array}{c}\text { Sand } \\
\left(\mathrm{g} \mathrm{kg}^{-1}\right)\end{array}$ & $\begin{array}{c}\text { Silte } \\
\left(\mathrm{g} \mathrm{kg}^{-1}\right)\end{array}$ & $\begin{array}{c}\text { Clay } \\
\left(\mathrm{g} \mathrm{kg}^{-1}\right)\end{array}$ & & & $\begin{array}{c}\text { Soil } \\
\left(\mathrm{g} \mathrm{cm}^{-3}\right)\end{array}$ & $\begin{array}{l}\text { Particle } \\
\left(\mathrm{g} \mathrm{cm}^{-3}\right)\end{array}$ & $\begin{array}{c}0.033 \mathrm{MPa} \\
(\mathrm{g} / 100 \mathrm{~g})\end{array}$ & $\begin{array}{l}1.5 \mathrm{MPa} \\
(\mathrm{g} / 100 \mathrm{~g})\end{array}$ & $\mathrm{H}_{2} \mathrm{O}(\%)$ & \\
\hline 1 & 602 & 293 & 105 & 64 & 390 & 1.75 & 2.92 & 15.42 & 8.10 & 7.32 & Sand \\
\hline 2 & 637 & 264 & 99 & 76 & 232 & 1.63 & 2.74 & 12.98 & 5.39 & 7.59 & Sand \\
\hline 3 & 676 & 208 & 116 & 51 & 560 & 1.60 & 2.60 & 11.62 & 4.47 & 7.15 & Sand \\
\hline \multicolumn{12}{|c|}{ Chemical characterization } \\
\hline & $\begin{array}{c}\mathrm{pH} \mathrm{H} \mathrm{H}_{2} \mathrm{O} \\
\left(\mathrm{mg} \mathrm{dm}^{-3}\right)\end{array}$ & $\begin{array}{c}\mathrm{P} \\
\left.(\mathrm{mg} \mathrm{dm})^{-3}\right)\end{array}$ & $\begin{array}{c}\mathrm{K}^{+} \\
\left(\mathrm{mg} \mathrm{dm}^{-3}\right)\end{array}$ & $\begin{array}{c}\mathrm{Ca}^{2+} \\
\left(\mathrm{mg} \mathrm{dm} \mathrm{dm}^{-3}\right)\end{array}$ & $\begin{array}{c}\mathrm{Mg}^{2+} \\
\left(\mathrm{mg} \mathrm{dm}^{-3}\right)\end{array}$ & $\begin{array}{c}\mathrm{Al}^{3+} \\
\left(\mathrm{cmol}_{c} \mathrm{dm}^{-3}\right)\end{array}$ & $\begin{array}{c}\mathrm{Na}^{+} \\
\left(\mathrm{cmol}_{\mathrm{c}} \mathrm{dm}^{-3}\right)\end{array}$ & $\begin{array}{c}\mathrm{SB} \\
(\mathrm{g} / \mathrm{kg})\end{array}$ & $\begin{array}{c}\text { CTC } \\
(\mathrm{g} / \mathrm{kg})\end{array}$ & $\begin{array}{c}\text { Organic } \\
\text { Matter }(\mathrm{g} / \mathrm{kg})\end{array}$ & $\begin{array}{c}\mathrm{V} \\
(\mathrm{g} / \mathrm{kg})\end{array}$ \\
\hline 1 & 7.10 & 1.73 & 55.0 & 10.80 & 5.45 & 0 & 0.08 & 16.87 & 16.97 & 6.18 & 97.05 \\
\hline 2 & 6.67 & 1.84 & 164.0 & 4.85 & 3.35 & 0 & 0.05 & 8.67 & 9.66 & 9.85 & 89.75 \\
\hline 3 & 6.51 & 2.85 & 200.0 & 4.45 & 1.85 & 0 & 0.06 & 6.87 & 8.52 & 11.84 & 80.63 \\
\hline
\end{tabular}


Table 2 - Species identified and analyzed for their chemical compositions

\begin{tabular}{cccc}
\hline Species and Pool & Family & Scientific name & Popular name \\
\hline 1 & Fabaceae & Arachis pintoi Benth.* & Amendoim-forrageiro \\
2 & Nyctaginaceae & Boerhavia diffusa L.** & Pega-pinto \\
3 & Boraginaceae & Heliotropium ternatum Vahl.** & Flor-branca \\
4 & Poaceae & Aristida adscensionis L.** & Capim-panasco \\
5 & - & - & Pool \\
\hline
\end{tabular}

* Higher expression in areas 2 and 3. ** Higher expression in areas 1 and 2.

From each area, four samples and the pool were collected from every species and from the pool. The sampling was chosen from each area and the cutting was done by means of a pair of pruning shears, at ground level, where all the aerial part of the plants shoots represented the sample of each area. In the rainy season, the crop was harvested when most species (more than $50 \%$ ) were in the reproductive stage (flowering and/or fruiting), since in the caatinga vegetation, the phenologycal events do not happen at a particular time and there is no standardization even within the same species.

The plant material sampled, about $500 \mathrm{~g}$, was taken to the Laboratório de Nutrição Animal of the CCA/UFPB, placed in an incubator at $65^{\circ} \mathrm{C}$ for 72 hours, prepared for dry matter determination (DM), organic matter (OM), mineral matter (MM), crude protein (CP), ether extract (EE), neutral detergent fiber (NDF) and acid detergent fiber (ADF), lignin, cellulose, hemicellulose and in vitro digestibility of DM according to the methodology described by Silva \& Queiroz (2002). NDF was estimated according to recommendations by Mertens (2002). Total carbohydrates (TC) were also estimated according to methodology of Sniffen et al. (1992), and soluble carbohydrates (CHO), according to Mertens (1997). The equations to calculate the total and soluble carbohydrates were: TC $=100-(\%$ $\mathrm{CP}+\% \mathrm{EE}+\%$ ash $)$ and $\mathrm{CHO}=100-(\% \mathrm{NDF}+\% \mathrm{CP}+\% \mathrm{EE}$ $+\%$ Ash).

The design selected was completely randomized in $5 \times 3$ factorial schemes, considering four species and the pool, and three areas, with four replications. The data were subjected to analyses of variance and the means were compared by using Tukey's test at 5\% probability with the SAS (1997) program.

\section{Results and Discussion}

According to data statistical analyses, there was an interaction $(\mathrm{P}<0.05)$ between plant species and the area sampled. Crude protein ranged from $7.85 \%$ to $19.23 \%$ in the species Aristida adscensionis and Arachis pintoi, respectively. The two species that presented lower crude protein values were Heliotropium ternatum and Aristida adscensionis in areas 1 and 2, respectively.

The average protein content found in this study for the caatinga herbaceous species, except for the panasco grass (Aristida adscensionis), may be considered quantitatively satisfactory, being higher than the values recommended in the literature for ruminants. Another important feature is that these species received no fertilization, and even so, the percentage of $\mathrm{CP}$ was higher in some of them. In the species Arachis pintoi, there was no difference among the areas, and this result is probably linked to its ability to fix nitrogen which is very important from the standpoint of animal nutrition and the nitrogen incorporation via atmospheric fixation by the bacteria present in its roots.

Regardless of the studied area, the species with the highest percentage of NDF was Aristida adscensionis. However, the percentage of lignin was not very high whereas the hemicellulose was $26.60 \%$. The grass hemicellulose content usually ranges from 14 to $25 \%$ in tropical species.

The ADF content of the species ranged from 39 to $48 \%$, when it was analyzed separately area by area, being verified very similar values among species in these areas. The ADF contents showed little variation among species (39 to 48\%) regardless of the areas analyzed. However, the contents of hemicellulose in the species had marked variation in the three areas: from $1.57 \%$ for the species Heliotropium ternatum to $29.60 \%$ for Aristida adscensionis, suggesting that the hemicellulose content tends to be higher in grasses than in dicots.

For lignin, the values found were very similar among species from the three areas, except for Heliotropium ternatum, which stood out with greater value in areas with an average of $10.18 \%$. The lignin content in plants can vary in dry matter from 2 to $12 \%$; however, from a nutritional standpoint, it is interesting that this value is kept low to avoid jeopardizing the digestibility of other nutrients.

The total carbohydrate of the species Arachis pintoi, Boerhavia diffusa and the pool in all three areas were around 64 and 68\% DM. The Heliotropium ternatum species and the Aristida adscensionis species exhibited higher 
percentages in the three scrub areas, at 75.15 and $82.80 \%$ respectively.

The non-fibrous carbohydrates varied markedly among species in the areas. The species Arachis pintoi varied from 11.74 to $21.75 \%$ in areas 3 and 1 . The species Boerhavia diffusa showed a non-fibrous carbohydrates variation from 5.23 to $17.87 \%$ in areas 2 and 1 . The soluble carbohydrates of species pool showed values from $6.96 \%$ in area 1 and $21.25 \%$ in area 3 . The non-fibrous carbohydrate contents vary, besides other factors because of the plant phenologic state. It can be seen in the course of the experiment, that the two species did not show uniformity in their phenology, which may be attributed to soluble carbohydrates variations.

In vitro digestibility of dry matter was above $50 \%$ for most species in the areas studied. The species Boerhavia diffusa in area 1 (66.8\%) had the highest value, and the lowest value was found for the Heliotropium ternatum in area 2 (38.4\%). Figure 3 shows that the highest percentages of lignin occurred in the species Heliotropium ternatum, suggesting reduction in digestibility. According to Euclid (1995), the DM accumulation during the growth and development of plants is primarily responsible for reduction in DM digestibility. This is probably due to the increased deposition of DM in the plant cell wall and the intensification of its lignification.

It is generally expected that plants of the same species have similar phenologic cycles, because they share the same environment. However, for Caatinga species, there was a disconnection between these cycles, probably associated with survival strategies, because if the plants showed uniform phenologic cycles, they might have disappeared when environmental conditions were unfavorable (Andrade et al. 2006). The differences in chemical composition among species observed in this study can be attributed to the fact that these species were different, and even growing in similar environmental conditions, they may have different chemical composition - a result of the genetic diversity of species (Van Soest, 1965).

Besides the differences observed in species and among species, another important feature lies in the difference in the conservation levels and in the physical and chemical characteristics of the soil in the areas under study, which certainly influenced fertility, moisture, and floristic and chemical composition of the species that make up these environments. When the chemical characteristics of the three areas were investigated, it was observed that area 3 , the most preserved area, did show higher concentrations of phosphorus, potassium and organic matter than the other areas.

In this study, it was possible to observe that the herbs studied had relatively higher fractions of DM, NDF and ADF values consistent with tropical forages as mentioned before. Wilson et al. (1991) stated that high temperatures, a hallmark of the semi-arid conditions, promote rapid lignifications of the cell wall, accelerating their metabolic activities.

In the two evaluation periods, a decrease in the protein content of the species pool during the transition from the wet season to the dry season was observed (Table 3). This decline was most pronounced in area 1 from $17.21 \%$ to $4.69 \%$ between seasons, respectively. The samples of areas 2 and 3 were very similar in the dry season: 8.15 and 8.79\% respectively. According to Pereira Filho et al. (1997) because of lack of rain, the CP content of dicotyledonous plants and grasses tended to fall.

Table 3 - Chemical composition of the species pool of in three areas over two assessment periods

\begin{tabular}{|c|c|c|c|c|c|c|}
\hline \multirow{3}{*}{ Item, \% } & \multicolumn{6}{|c|}{ Area * Period } \\
\hline & \multicolumn{2}{|c|}{ Area 1} & \multicolumn{2}{|c|}{ Area 2} & \multicolumn{2}{|c|}{ Area 3} \\
\hline & Rainy & Dry & Rainy & Dry & Rainy & Dry \\
\hline Organic matter & $87.10 \mathrm{Aa}$ & $85.77 \mathrm{Ba}$ & $84.22 \mathrm{Bb}$ & $88.73 \mathrm{Aa}$ & $87.02 \mathrm{Ab}$ & $91.26 \mathrm{Aa}$ \\
\hline Mineral matter & $14.22 \mathrm{Aa}$ & $12.90 \mathrm{Ab}$ & $15.75 \mathrm{Aa}$ & $11.26 \mathrm{Bb}$ & $12.97 \mathrm{Ba}$ & $8.74 \mathrm{Cb}$ \\
\hline Crude protein & $17.21 \mathrm{Aa}$ & $4.69 \mathrm{Bb}$ & $14.70 \mathrm{Ba}$ & $8.15 \mathrm{Ab}$ & $12.11 \mathrm{Ca}$ & 8.79Ab \\
\hline Ether extract & $2.51 \mathrm{Ba}$ & $0.98 \mathrm{Cb}$ & $3.88 \mathrm{Aa}$ & $2.38 \mathrm{ABb}$ & $2.36 \mathrm{Ba}$ & $3.24 \mathrm{Aa}$ \\
\hline Lignin & $8.58 \mathrm{Bb}$ & $14.69 \mathrm{Aa}$ & $6.13 \mathrm{Cb}$ & $14.39 \mathrm{Aa}$ & $11.00 \mathrm{Ab}$ & $15.76 \mathrm{Aa}$ \\
\hline Celulose & $15.80 \mathrm{Ab}$ & $23.58 \mathrm{Aa}$ & $20.15 \mathrm{Aa}$ & $21.34 \mathrm{Aa}$ & $19.08 \mathrm{Ab}$ & $26.07 \mathrm{Aa}$ \\
\hline Hemicellulose & $5.66 \mathrm{Ba}$ & $1.40 \mathrm{Ab}$ & $8.62 \mathrm{Aa}$ & $1.30 \mathrm{Ab}$ & $2.85 \mathrm{Ca}$ & $2.25 \mathrm{Aa}$ \\
\hline Total carbohydrates & $67.37 \mathrm{Bb}$ & $80.10 \mathrm{Aa}$ & $65.66 \mathrm{Bb}$ & $78.18 \mathrm{Aa}$ & $72.54 \mathrm{Ab}$ & 79.22 Aa \\
\hline Non-fiber carbohydrates & $14.56 \mathrm{Ba}$ & $6.95 \mathrm{Cb}$ & $13.21 \mathrm{Ba}$ & $12.90 \mathrm{Ba}$ & $21.25 \mathrm{Aa}$ & $19.33 \mathrm{Aa}$ \\
\hline
\end{tabular}

* In the line for the same column area, the mean followed by the same lowercase letter, and in the line for columns of different area, the mean followed by the same capital letter do not differ statistically at 5\% probability according to Tukey test. 

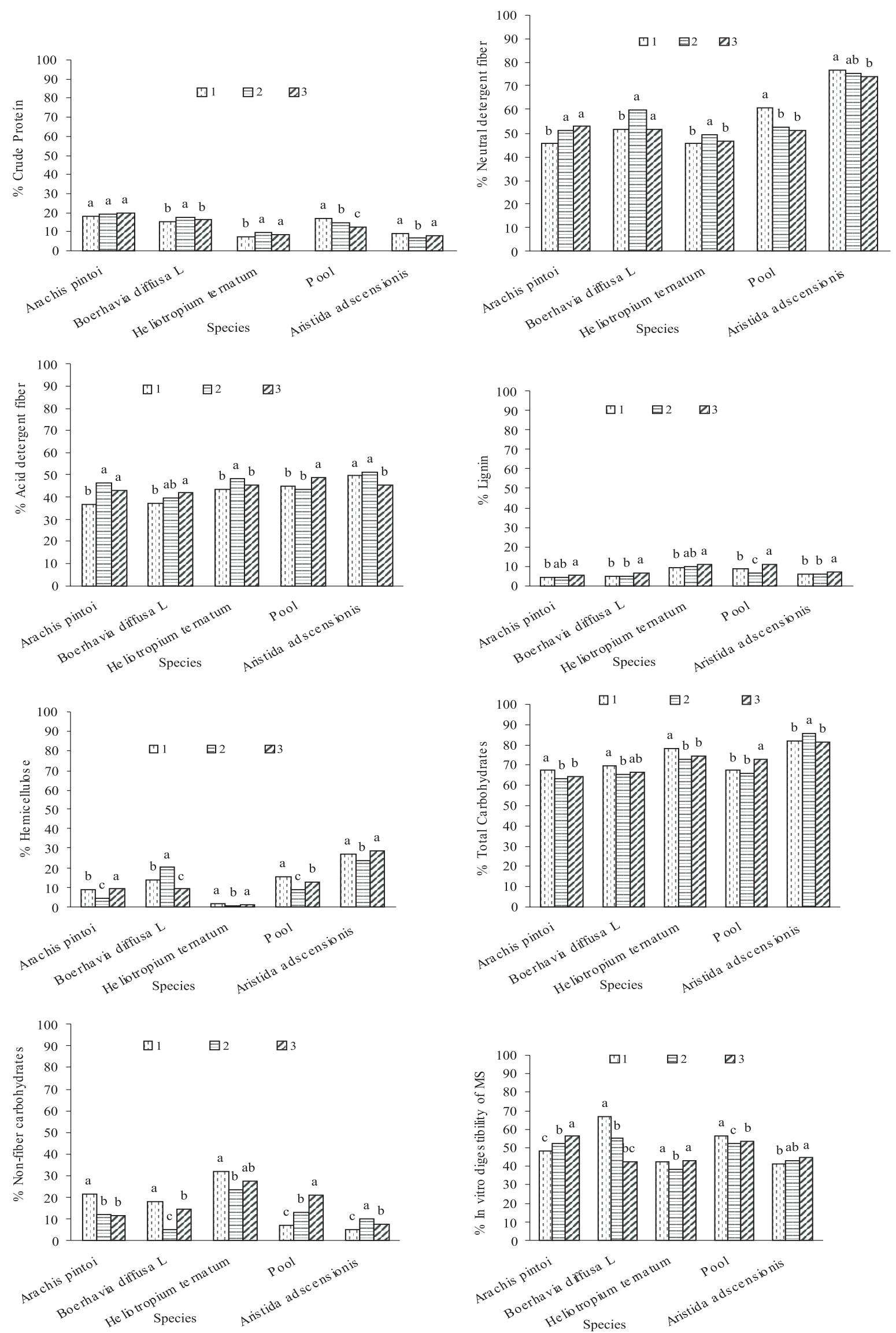

The means followed by small letters on the bars of each area differ $(\mathrm{P}<0.05)$ from each other as determined by Tukey test.

Figure 3 - Chemical composition of four species of herbs and pool in the Caatinga. 
Area 1 soil showed a greater amount of calcium and this element is directly related to kinase, which is an enzyme that catalyzes protein activities (Raven \& Evert, 2007). According to the authors, more than 30 protein kinase have been identified and ten of these are calcium dependent. Another important feature to consider is the amount of magnesium, which was much lower in areas 2 and 3. Magnesium is a nutrient required for the phosphorylation and protein synthesis (Malavolta et al., 1997) which may have induced a change in the protein content of the species studied.

The neutral detergent fiber of the pool did not differ in areas 3 and 2 in the rainy season, with values of 51.29 and $52.41 \%$ respectively. In contrast to the dry season, similarity was found between the NDF of the pool in areas 1 and 2. In area 3, it was found low contents of NDF in DM during the dry season in comparison to other areas.

The amount of ADF did not differ between areas 1 and 2; however, those of the pool were affected by the season in all areas, with an increase of this fraction in the transition from rainy to dry season. Probably, there were a leaf reduction and an increase in the stem length, increasing acid detergent fiber content, and reducing the dry matter digestibility. The lignin and cellulose of the pool increased in all areas in the dry season. As for the hemicellulose, differences in levels between areas did occur, but only in the rainy season, when the pool of area 3 showed a higher content of hemicellulose in comparison to other areas.

In the pool, the highest total carbohydrate was observed in three samples from area 3 in the rainy season, whereas during the dry season, there were no differences in the percentages of carbohydrates in the pool of the areas. The non-fiber carbohydrate of the pool did not differ between areas, with higher percentage in the pool of area 3 along two seasons. Differences between seasons were observed for just one area where the collected material showed a lower percentage of non-fiber carbohydrate in the dry season $(6.95 \% \mathrm{DM})$.

In vitro digestibility of the dry matter in the pool did not differ between the areas in the rainy season. However, from the rainy season to the dry season, there was a reduction of digestibility of the pool, which was lower in the pool of area 1 (26.20\% in DM).

The data collected in the present study for the chemical composition of the pool of herbs showed significant changes in plant material available to the animals between the two seasons (rainy and dry). These are important informations for animal nutrition, because they provide subsidies for the evaluation of nutrient deficiencies based on the chemical composition of the plants that animals consume at different times.

There was no effect of studied areas on the dry matter of the panasco grass (Aristida adscensionis L.) (Table 4). However, there was a period effect in view of the increased dry matter found in the three areas assessed during the dry season. Ramirez et al. (1995), doing research on buffelgrass, a grass adapted to the semiarid conditions, stated that in Mexico, the buffel grass had its pasture composition and quality greatly altered during the year, a trend observed in this study for plants of the caatinga, and more specifically for Aristida adscensionis L grass.

The DM content increased in dry season, probably due to its reduction in leaf percentage and an increase in stem growth and also due to the dehydration of plant material.

Crude protein exhibited a major reduction in between seasons, with a decrease of approximately $50 \%$ from the

Table 4 - Chemical composition of panasco grass (Aristida adscensionis L.) from three areas during two assessment periods

\begin{tabular}{|c|c|c|c|c|c|c|}
\hline \multirow{3}{*}{ Item, \% } & \multicolumn{6}{|c|}{ Area * Period } \\
\hline & \multicolumn{2}{|c|}{ Area 1} & \multicolumn{2}{|c|}{ Area 2} & \multicolumn{2}{|c|}{ Area 3} \\
\hline & Rainy & Dry & Rainy & Dry & Rainy & Dry \\
\hline Dry matter & $48.77 \mathrm{Ab}$ & $64.08 \mathrm{Ba}$ & $49.87 \mathrm{Ab}$ & $66.80 \mathrm{Ba}$ & $46.98 \mathrm{Ab}$ & $71.06 \mathrm{Aa}$ \\
\hline Organic matter & $91.85 \mathrm{Aa}$ & $87.92 \mathrm{Bb}$ & $93.15 \mathrm{Aa}$ & $91.65 \mathrm{Aa}$ & $91.81 \mathrm{Aa}$ & $90.66 \mathrm{Aa}$ \\
\hline Mineral matter & $8.15 \mathrm{Ab}$ & $12.07 \mathrm{Aa}$ & $6.85 \mathrm{Aa}$ & $8.35 \mathrm{Ba}$ & $8.20 \mathrm{Aa}$ & $9.34 \mathrm{Ba}$ \\
\hline Crude protein & $8.87 \mathrm{Aa}$ & $4.23 \mathrm{Ab}$ & $6.44 \mathrm{Ba}$ & $4.26 \mathrm{Ab}$ & $8.25 \mathrm{Aa}$ & $4.11 \mathrm{Ab}$ \\
\hline Neutral detergent fiber & $76.64 \mathrm{Aa}$ & $80.15 \mathrm{Aa}$ & $75.30 \mathrm{Ab}$ & $80.23 \mathrm{Aa}$ & $74.03 \mathrm{Aa}$ & $77.71 \mathrm{Aa}$ \\
\hline Fiber in acid detergent & $49.36 \mathrm{Ab}$ & $58.67 \mathrm{Aa}$ & $51.40 \mathrm{Aa}$ & $55.53 \mathrm{Aa}$ & $45.40 \mathrm{Bb}$ & $54.44 \mathrm{Aa}$ \\
\hline Ether extract & $1.36 \mathrm{Aa}$ & $1.34 \mathrm{Aa}$ & $1.38 \mathrm{Aa}$ & $1.41 \mathrm{Aa}$ & $2.09 \mathrm{Aa}$ & $1.58 \mathrm{Aa}$ \\
\hline Lignin & $5.60 \mathrm{Ab}$ & $12.91 \mathrm{Aa}$ & $5.54 \mathrm{Aa}$ & $7.89 \mathrm{Ba}$ & $6.80 \mathrm{Aa}$ & $7.99 \mathrm{Ba}$ \\
\hline Celulose & $13.10 \mathrm{Bb}$ & $21.75 \mathrm{Aa}$ & $21.17 \mathrm{Aa}$ & $21.19 \mathrm{Aa}$ & 18.59Aa & $21.05 \mathrm{Aa}$ \\
\hline Hemicellulose & $27.27 \mathrm{Aa}$ & $21.47 \mathrm{Ab}$ & $23.89 \mathrm{Aa}$ & $24.69 \mathrm{Aa}$ & $28.62 \mathrm{Aa}$ & $23.25 \mathrm{Ab}$ \\
\hline Total carbohydrates & $81.61 \mathrm{Ba}$ & $82.35 \mathrm{Ba}$ & $85.32 \mathrm{Aa}$ & $85.97 \mathrm{Aa}$ & $81.47 \mathrm{Bb}$ & $84.95 \mathrm{ABa}$ \\
\hline Non-fiber carbohydrates & $4.98 \mathrm{Ca}$ & $2.20 \mathrm{Cb}$ & $10.02 \mathrm{Aa}$ & $5.74 \mathrm{Bb}$ & $7.43 \mathrm{Ba}$ & $7.25 \mathrm{Aa}$ \\
\hline DM in vitro digestibility & $41.08 \mathrm{Aa}$ & $23.37 \mathrm{Ab}$ & $42.80 \mathrm{Aa}$ & $23.15 \mathrm{Ab}$ & $44.40 \mathrm{Aa}$ & $22.84 \mathrm{Ab}$ \\
\hline
\end{tabular}

* In the line for the same column area, the mean followed by the same lower case letter, and in the line for columns of different area, the mean followed by the same capital letter do not differ statistically at $5 \%$ probability according to Tukey test. 
rainy season to the dry season. This reduction was mainly associated to the senescence and abscission of leaves found most strongly in the dry season. With the maturing of tropical forage, crude protein levels tend to drop significantly. Dantas Neto et al. (2000) observed that the CP content of buffel grass decreased linearly as age of the plant increased from $12.4 \%$ to $6.0 \%$ from 35 days to 110 days.

NDF and the ADF showed values compatible with data from tropical grasses. The lignin and cellulose increased in the dry season and the hemicellulose decreased, a result which is probably associated to a reduced cellular content and increased lignifications of plant tissues.

The total carbohydrates content exceeded $80 \%$ of dry matter and there was no variation between seasons whereas the content of non-fibrous carbohydrates showed differences between both areas in different seasons. In the rainy season, in area 1, Aristida adscensionis L. showed the lowest non-fiber carbohydrate and in area 2 the highest. In the dry season, it was observed in area 3, the highest level of non-fiber carbohydrates, and in area 1 this remained at the lowest level. When comparing these periods, with the exception of area 3 , there was a decrease in non-fibrous carbohydrate from the rainy season to the dry season.

Dry matter in vitro digestibility of Aristida adscensionis L. did not differ between areas, but between periods there was a reduction of approximately $50 \%$ from the rainy season to dry season. In the dry period, the process of cell wall lignifications is stronger, which causes a reduction in the dry matter digestibility.

Panasco grass (Aristida adscensionis L.) is an important contribution to forage in the diet of goats and sheep in the semi-arid, and therefore its chemical composition is the most important to be known. This participation of panasco grass in the diet of goats was studied by Araujo Filho et al. (1996) who noticed a participation of $61.2 \%$ of it, confirming, therefore, the importance of this grass.

The studied plants showed in their chemical composition crude protein values close to $15 \%$; while those values of NDF and ADF remained within the range found for tropical grasses (Tables 3 and 4 ). It was also noticed that the mineral content of these plants is very high. In most studies on the caatinga species high values of mineral content have been reported in these plants. Works by made Lima Junior (2006) and Pinto (unpublished data) indicate this trend. Lima Junior (2006) found $10.25 \%$ of the minerals in the dry matter of these species whereas Pinto found percentages ranging from 8.21 to $15.03 \%$.

Digestibility of dry matter of the caatinga species studied in the rainy season was all above $50 \%$. Digestibility of dry matter above $50 \%$ did not show the dry matter intake as being restricted to the filling effect (Van Soest, 1965). However, in the dry season, the digestibility of the plants decreased significantly, falling to about $30 \%$, which can lead to lower dry matter intake by ruminants, reducing animal production, besides its lower nutritional value.

In a study on the caatinga species, Araujo Filho et al. (2002) stated that the nutritional value of the woody caatinga changes throughout the year. In this study, it was also observed variations in the values of bromoltologic indicators, in the same way i.e.,in the same area, the values vary with the conditions of rainfall distribution along the year.

According to Pereira Filho et al. (1997), the herb layer, chemical composition, palatability, digestibility and intake are influenced by the time of the year, since crude protein and non-fibrous carbohydrates contents decrease the levels of neutral fiber detergent, and lignin increases as the rainy season approaches to its end. According to Van Soest (1965), increasing levels of structural carbohydrates and lignin and reduction in cellular content invariably cause reduction in digestibility.

Consequently, during the dry season, with the absence of rains, which makes it possible the renewal of plant regrowth, the remaining vegetation loses its nutritional value progressively and rapidly. Finally, because of the high variability of the rainfall, it is suggested that more studies should be done based on parameters of performance indicators about animals fed on grass species found in the caatinga.

\section{Conclusions}

The bromatologic composition of the caatinga herbaceous species varies depending on the area conservation state and the season of the year (dry or rainy season). The pool of herbaceous species in the rainy season presents qualitative indicators that allow to classify these plants as suitable for consumption by ruminant animals already adapted to the semiarid conditions.

\section{Referências}

ANDRADE, A.P.; SOUZA, E.S.; SILVA, D.S. et al. Produção animal no bioma caatinga: paradigmas dos pulsos-reserva. Revista Brasileira de Zootecnia, v.35, p.138-155, 2006 (supl. especial).

ARAÚJO, E.L.; FERRAZ, E.M.N. Processos ecológicos mantenedores da diversidade vegetal na caatinga: estado atual do conhecimento. In: CLAUDINO-SALES, V. (Ed.). Ecossistemas brasileiros: manejo e conservação. Fortaleza: Expressão Gráfica e Editora, 2003. p.115-128. 
ARAÚJO FILHO, J.A.; CARVALHO, F.C.; SILVA, N.L. Fenologia y valor nutritivo de follajes de algunas espécies forrajeras de la Caatinga. Agroforesteria en las Américas, v.9, n.33-34, p.3337, 2002.

ARAÚJO FILHO, J.A.; GADELhA, J.A.; LEITE, E.R. et al. Composição botânica e química da dieta de ovinos e pastoreio combinado na região dos Inhamuns, Ceará. Revista Brasileira de Zootecnia, v.25, n.3, p.383-395, 1996.

EUCLIDES, V.P.B. Valor alimentício de espécies forrageiras do gênero Panicum. In: SIMPÓSIO SOBRE MANEJO DA PASTAGeM, 12., 1995, Piracicaba. Anais... Piracicaba: FEALQ, 1995. p.245-276.

DANTAS NETO, J.; SILVA, J.F.A.S.; FURTADO, D.A. et al. Influência da precipitação e idade da planta na produção e composição química do capim-buffel. Pesquisa Agropecuária Brasileira, v.35, n.9, p.413-420, 2000.

EMPRESA BRASILEIRA DE PESQUISA E AGROPECUÁRIA EMBRAPA. Manual de métodos de análise de solo. 2.ed. Rio de Janeiro: Embrapa: Centro Nacional de Pesquisa em Solos, 1997. 212p.

FORSYTHE, W.M. Física de suelos: manual de laboratorios. San Jose: Instituto Interamericano de Ciências Agrícolas, 1975. 212p.

LIMA, P.C.F.; OLIVEIRA, E.B.; MACHADO, S.A. Equações para estimativa de biomassa de espécie de Prosopis no semiárido brasileiro. Boletim de Pesquisa Florestal, v.32-33, p.67-70, 1996.

LIMA JÚNIOR, V. Caracterização da dieta e avaliação de métodos de estimativa de consumo em caprinos suplementados na caatinga. 2006. 81f. Dissertação (Mestrado em Zootecnia) - Centro de Ciências Agrárias/ Universidade Federal da Paraíba, Areia.

MALAVOLTA, E.; VitTe, C.G.; OLIVEIRA, S.A. Avaliação do estado nutricional das plantas: princípios e aplicação. 2.ed. Piracicaba. 1997. 319p.

MERTENS, D.R. Gravimetric determination of amylase-treated neutral detergent fiber in feeds with refluxing in beakers or crucibles: collaborative study. Journal of AOAC International, v.85, p.1217-1240, 2002.

MERTENS, D.R. Creating a system for meeting the fiber requirements of dairy cows. Journal of Dairy Science, v.80, p.1463-1481, 1997.
PEREIRA FILHO, J.M.; ARAÚJO FILHO, J.A.; REGO M.C. et al. Variações plurianuais da composição florística do estrato herbáceo de uma caatinga raleada, submetida ao pastejo alternado ovinocaprino. Revista Brasileira de Zootecnia, v.26, n.2, p.234-239, 1997.

RAMIREZ, R.G.; HUERTA J.M.; KAWAS, J.R. et al. Performance of lambs grazing in a buffelgrass (Cenchrus ciliaris) pasture and estimation of their maintenance energy requirement for growth. Small Ruminant Research, v.17, p.117-121, 1995.

RAVEN, P.H.; EVERT, F.R. Biologia vegetal. 7.ed. Rio de Janeiro: Guanabara Koogan, 2007. 760p.

RAPINI, A.; QUEIROZ, L.P.; GIULIETTI, A.M. PPBio: Programa de Pesquisa em Biodiversidade do Semi-árido. In: QUEIROZ, L.P.; RAPINI, A.; GIUliETTI, A.M. (Eds.) Amplo conhecimento da biodiversidade do semi-árido brasileiro. Disponível em: <http://www.uefs.br/ppbio/cd/ portugues/htm> Acesso em: 24/10/2006.

SANTOS, G.R.A.; BATISTA, A.M.V.; GUIM, A. et al. Composição quimica e degradabilidade in situ da ração em ovinos em área de caatinga no sertão de Pernambuco. Revista Brasileira de Zootecnia, v.38, n.2, p.384-391, 2009.

SILVA, D.J.; QUEIROZ, A.C. Análise de alimentos: métodos químicos e biológicos. Viçosa, MG: Universidade Federal de Viçosa, 2002. 235p.

SNIFFEN, C.J.; O'CONNOR, J.D.; Van SOEST, P.J. A net carbohydrate and protein system for evaluating cattle diets. II. Carbohydrate and protein availability. Journal of Animal Science, v.70, p.3562-3577, 1992.

STATISTICAL ANALYSES SYSTEM - SAS. Users' guide. Cary: SAS. Institute Inc., 1997. 156p.

VAN SOEST, P.J. Symposium on factors influencing the voluntary intake of herbage by ruminants: voluntary intake in relation to chemical composition and digestibility. Journal Animal Science, v.24, n.3, p.834-843, 1965.

WILSON, J.R. DEINUM, B.; ENGELS, F.M. Temperature effects on anatomy and digestibility of leaf and stem of tropical and temperate forage species. Journal Agriculture Science, v.39, n.1, p.31-48, 1991. 